\title{
Pengaruh Kombinasi Metformin dan Ekstrak Air Meniran (Phyllanthus Niruri Linn.) terhadap Perbaikan Status Obesitas Tikus Sprague Dawley Jantan
}

\section{Effect Combination of Metformin and Meniran (Phyllanthus niruri Linn.) Water Extract on the Improvement of Obesity Status Male Sprague Dawley Rats}

Ai Sri Kosnayani*1, Edi Dharmana², Suharyo Hadisaputro², Ignatius Riwanto²

\section{ABSTRAK}

Latar Belakang: Perubahan gaya hidup dan pola makan menyebabkan tingginya angka kejadian obesitas di seluruh dunia yaitu 13\% pada tahun 2016 dan 21,8 \% kejadian obesitas di Indoneia pada tahun 2018. Perbaikan status obesitas dapat dilakukan melalui jalur farmakologik ataupun non farmakologik. Metformin dan meniran (Phyllanthus niruri Linn.) mempunyai fungsi untuk menurunkan penyerapan asupan makanan.

Tujuan: menganalisis pengaruh kombinasi metformin dan ekstrak air meniran (Phyllanthus niruri Linn.) terhadap perbaikan status obesitas tikus Sprague Dawley jantan.

Metode: multigroup time series design. Dua puluh empat ekor tikus dibuat obesitas dengan cara diberi pakan tambahan lemak sapi cair dan fruktosa terhadap pakan dasar AIN93G selama 5 minggu. Obesitas ditentukan dengan indeks Lee $>300$. Sampel dikelompokkan menjadi 4 kelompok, kelompok 1 diberi metformin $45 \mathrm{mg} / \mathrm{kg} \mathrm{BB} /$ hari, kelompok 2 diberi ekstrak air meniran $400 \mathrm{mg} / \mathrm{kg} \mathrm{BB} /$ hari, kelompok 3 diberi kombinasi keduanya, dan kelompok 4 kontrol.

Hasil: Setelah 28 hari perlakuan dan dihitung pengaruh antar perlakuan menggunakan Duncan Multiple Range Test $(\rho<0,05)$, terdapat perbedaan kenaikan berat badan dan perubahan indeks Lee antara ketiga kelompok perlakuan, walaupun indeks Lee $>300$.

Kesimpulan: pemberian kombinasi ekstrak air meniran dan metformin dapat mengendalikan kenaikan berat badan dan menurunkan indeks Lee.

Kata Kunci: Metformin, Meniran, Obesitas, Indeks Lee

\section{ABSTRACT}

Background: Changes in lifestyle and diet led to a high incidence of obesity worldwide, namely $13 \%$ in 2016 and $21.8 \%$ of obesity in Indonesia in 2018. Improvement of obesity status can be done through pharmacologic or non-pharmacologic channels. Metformin and meniran (Phyllanthus niruri Linn.) Have a function to reduce the absorption of food intake.

Objective: analyze the effect of the combination of metformin and meniran water extract (Phyllanthus niruri Linn.) on the improvement of the obesity status of male Sprague Dawley rats.

Methods: multigroup time series design. Twenty-four rats were made obese by being fed feed with liquid cow fat and fructose on AIN93G basic feed for 5 weeks. Obesity was determined by the Lee index $>300$. Samples were grouped into 4 groups, group 1 was given metformin $45 \mathrm{mg} / \mathrm{kg}$ BW / day, group 2 was given meniran water extract $400 \mathrm{mg} / \mathrm{kg}$ BW/day, group 3 was given a combination of both, and group 4 control.

Results: During the study there were differences in the weight of feed and calorie intake in each treatment group. After 28 days of treatment and calculated the effect between treatments using the Duncan Multiple Range Test $(\rho<0.05)$, there were differences in weight gain and changes in Lee index between the three treatment groups $(\rho<0.05)$, even though the Lee index was $>300$

Conclusion: giving a combination of meniran water extract and metformin can control weight gain and decrease the Lee index.

Keywords: Metformin, Meniran, Obesity, Lee Index

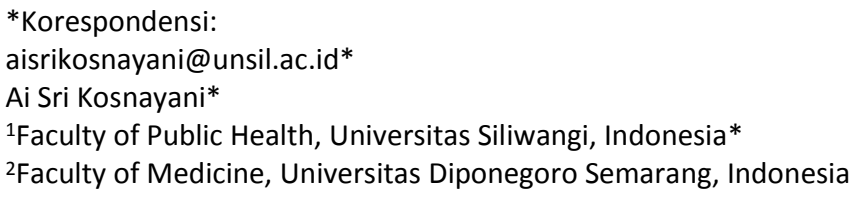




\section{PENDAHULUAN}

Obesitas dikaitkan dengan gangguan metabolisme seperti resistensi insulin, peradangan dan hiperkoagulobilitas yang semuanya dapat dipahami sebagai konsekuensi dari disfungsi jaringan adiposa. Disfungsi jaringan adiposa dapat dilihat sebagai kombinasi dari perubahan pro-inflamasi pada jaringan adiposa dan perubahan fungsi endokrin jaringan adiposa $^{1}$. Ditinjau dari segi kesehatan obesitas merupakan salah satu penyakit gizi salah yang diakibatkan oleh konsumsi makanan yang melebihi kebutuhan. Pada tahun 2016 dilaporkan dari seluruh penduduk dunia 39\% orang dewasa overweight dan $13 \%$ obesitas. ${ }^{2}$ Pervalensi obesitas di Indonesia menunjukkan tren peningkatan yaitu $10,5 \%$ pada Tahun 2007, menjadi $14,8 \%$ pada Tahun 2013 dan 21,8\% pada Tahun 2018 dan 13.9\%nya adalah pravelensi obesitas laki-laki. ${ }^{3}$ Resiko dampak obesitas terhadap fertilitas pada laki-laki lebih besar dibandingkan pada perempuan. Penelitian lain melaporkan semakin meningkat berat badan maka produksi testosteron kian menurun ${ }^{4}$.

Manajemen obesitas dapat dengan cara farmakologik dan non farmakologik. Meningkatkan aktifitas fisik dan menurunkan asupan makanan, sehingga diharapkan berat badan menjadi ideal dan menurunkan risiko obese sebagai intervensi non-farmakologik dan farmakologik yaitu dengan cara mengkonsumsi obat yang dapat menekan rasa lapar atau meningkatkan sensitivitas insulin ${ }^{5}$. Dilaporkan intervensi non-farmakologik perlu disertai dengan intervensi farmakologik, karena kerusakan jaringan atau penuruan fungsi organ tubuh (yang dapat menyebabkan obesitas) tidak dapat diperbaiki dengan intervensi non-farmakolgi.

Metformin (dimethylbiguanide) adalah agen insulin-sensitizing dan anti hiperglikemik yang digunakan dalam pengobatan diabetes mellitus tipe 2, dapat memperbaiki status obesitas, menurunkan tekanan darah dan inflamasi yang direkomendasikan WHO.6,7 Metformin dalam tubuh bekerja dengan merangsang sintesis glikogen intraseluler, meningkatkan sensitivitas insulin dan serapan glukosa otot, menurunkan produksi glukosa hati (penghambatan glukoneogenesis), dan penyerapan glukosa usus, serta mengganggu aktivitas mitokondria. ${ }^{7}$ Efek samping paling umum dari Metformin adalah gejala gastrointestinal, termsuk mual dan muntah, dan efek samping yang paling serius adalah asidosis laktat terutama pada pasien diabetes dengan disfungsi hati dan ginjal ${ }^{8}$.

Phyllanthus niruri atau meniran merupakan salah satu tanaman obat herbal yang mempunyai khasiat luas, seperti aktivitas antivirus melawan hepatitis B, antimikroba, hepatoprotektif, antikanker, dan agen hipokalsemik ${ }^{9}$. Analisis fitokimia pada ekstrak meniran memberikan reaksi positif untuk kelompok karbohidrat, alkaloid, flavonoid, glikosida, saponin, steroid dan $\operatorname{tanin}^{10}$ yang memberikan sifat aktivitas antioksidan. ${ }^{11}$ Hasil penelitian pada ekstrak meniran menunjukkan bahwa meniran dapat menurunkan berat badan mencit diabetes yang diinduksi aloksan. ${ }^{12,13}$ Hasil penelitan lain menunjukkan terjadi perbaikan resistensi insulin pada tikus obesitas yang diberi kombinasi metformin dan ekstrak air meniran ${ }^{14}$.

Penelitian pada tikus winstar, ekstrak air daun meniran tidak menunjukkan toksisitas terutama pada sistem hepatobiler dan ginjal baik pada pemberian dosis rendah $(2000 \mathrm{mg} / \mathrm{kg} \mathrm{bb})$ ataupun dosis tinggi $(5000 \mathrm{mg} / \mathrm{kg}$ bb). Selain itu, secara hematologis hasil penelitian juga tidak menunjukkan efek samping pada dosis rendah dan tinggi. Berdasarkan hal tersebut dapat disimpulkan bahwa ekstrak air meniran dianggap tidak beracun dan memiliki LD50 lebih besar dari $5000 \mathrm{mg} / \mathrm{kg}$ bb dengan tidak ada efek samping setelah pemberian tunggal ${ }^{15}$. Ekstrak air meniran walaupun tidak bersifat toksik dalam penggunaan tetap harus diperhitungkan dosisnya karena dalam ekstrak air meniran ada zat anti nutrisi oksalat yang menyebabkan nefrosis oxalate irreversible yang dapat mengganggu penyerapan nutrisi logam divalen $\mathrm{C}^{2+}$, $\mathrm{Mg}^{2+}, \mathrm{Fe}^{2+}$ ) dan asam lemak membentuk garam yang tidak larut. ${ }^{16}$ Berdasar pada teori diatas, penelitian ini bertjuan untuk melihat efektivitas pemberian metformin yang dikombinasikan dengan ekstrak air meniran pada Tikus Sprague dawley Jantan sebagai langkah awal dalam penelitian lanjutan penggunaan Phyllantus niruri Linn. Sebagai manajemen farmakologik menurunkan obesitas.

\section{METODE}

Multi group time series design didasarkan pada penerapan beberapa pengukuran, sebelum dan setelah perlakuan, untuk mendokumentasikan pola atau kecenderungan hasil perlakuan dengan menggunakan hewan coba sebagai subjek penelitian. Status obesitas ditentukan dengan menggunakan indeks yang merupakan hasil perhitungan dari hasil pengukuran berat dan panjang badan yang dilakukan sekuensial setiap setelah 7 perlakuan sebanyak 4 kali. Status obesitas ditentukan dengan menggunakan persamaan matematis ${ }^{17}$ :

Indeks Lee $=\frac{\sqrt[3]{B B}}{P B} \times 1000$ (tikus dinyatakan obesitas jika indeks Lee $>300$ ). Dua puluh empat ekor tikus Sprague dawley jantan yang berumur 4 minggu dan berat badan 150 - 170 gram diaklimatisasi sesuai prosedur di Laboratorium Pangan dan Gizi PAU UGM selama 3 hari. Hewan coba tersebut diberi pakan standar AIN93G dan diinduksi dengan fruktosa cair $1 \mathrm{gr} /$ hari dan lemak sapi cair $2 \mathrm{gr} /$ hari, setiap hari selama 35 hari. Setiap 7 hari berat dan panjang badan diukur lalu dihitung indeks Lee. Tikus ditetapkan obesitas, indeks Lee $\geq 300$. Tikus obesitas dikelompokkan secara acak ke dalam 4 sub kelompok terdiri dari 6 ekor. Sebelum mulai perlakuan semua tikus diambil data berat dan panjang badan sebagai data awal. Perlakuan diberikan pada Kelompok I: metformin dengan dosis $45 \mathrm{gr} / \mathrm{kg}$ bb/hari; Kelompok II: ekstrak air meniran dengan dosis $400 \mathrm{mg} / \mathrm{kg} \mathrm{bb} /$ hari; dan Kelompok III: kombinasi metformin dengan dosis $45 \mathrm{gr} / \mathrm{kg}$ bb/hari dan ekstrak air meniran dengan dosis $400 \mathrm{mg} / \mathrm{kg}$ bb/hari; dan Kelompok Kontrol : saline. Ekstrak air meniran dibuat dengan maserasi air dengan tujuan untuk menghindari sisa residu pelarut. Pemberian dilakukan dengan cara sonde, ekstrak air meniran dan metformin dilarutkan dalam saline.

Perlakuan diberikan setipa hari pukul 07.00, 
setiap setelah 7 hari perlakuan dilakukan pengukuran berat dan panjang badan. Pemberian perlakuan dilakukan selama 28 hari, sehingga diperoleh data serial awal, 7 hari setelah penelitian (minggu 1), 14 hari (minggu 2), 21 hari (minggu 3), dan 28 hari (minggu 4). Analisis statistik disajikan dalam bentuk data univarat (mean, SD, minimum, maksimum), dan bivariat (One way Anova dan Kruskall Walls). Hewan coba diperoleh dari Laboratorium Pangan dan Gizi PAU UGM. Ethical Clearence (No. 358/EC/FK-RSDK/2016) diperoleh dari Komisi Etik Penelitian Kesehatan dan Kedokteran Universitas Diponegoro Semarang.

\section{HASIL DAN PEMBAHASAN}

Penggunaan subjek penelitian yang berasal dari tikus Sprague dawley galur inbred sama, berat badan hampir sama, umur dan jenis kelamin sama, cara pemeliharaan, pakan sama, dan perlakuan sonde sama serta pengamatan sama, maka respon perubahan pada parameter-parameter pengamatan dianggap sama pada setiap individu hewan coba. Keadaan yang berbeda dari masing-masing kelompok dianggap terjadi sebagai akibat dari perlakuan yang berbeda. Identifikasi obesitas dalam penelitian ini dimulai dengan terlihatnya peningkatan indeks Lee pada sampel yang diperiksa pada minggu kelima setelah induksi dengan lemak sapi cair $2 \mathrm{~g} /$ hari dan fruktosa cair $1 \mathrm{~g} /$ hari.

Kenaikan berat badan tergantung dari keseimbangan antara asupan dan keluaran energi. Dalam penelitian ini hitung asupan kalori hewan coba dengan cara mengkonversi masa pakan yang dimakan dengan jumlah kalori yang tergabung dalam tiap gram pakan AIN93G ( I gram = 3,8 Kkal). Hasil perhitungan asupan kalori setiap minggu penelitian dapat dilihat Gambar 1.

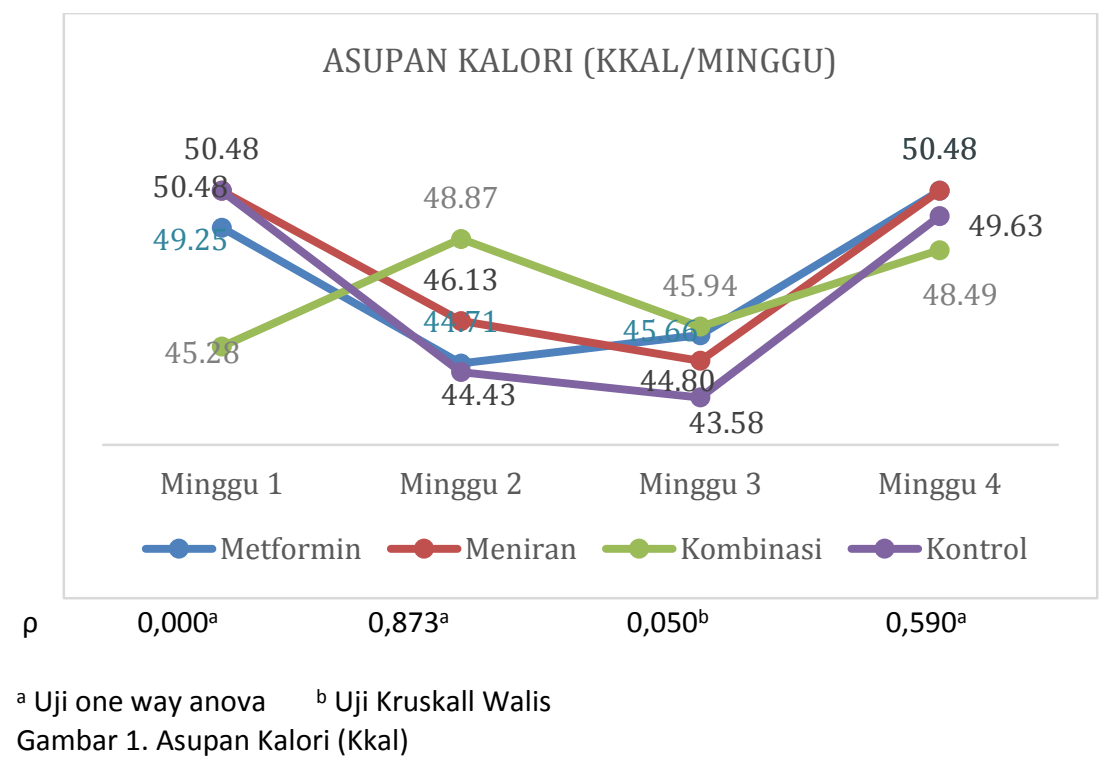

Data pada Gambar 1 menunjukkan bahwa asupan kalori tertinggi terjadi pada minggu pertama yaitu kelompok tikus yang metformin dan kelompok control $(50,489 \mathrm{KKal} / \mathrm{minggu})$ dan pada minggu keempat kelompok kontrol $(50,48 \mathrm{KKal} / \mathrm{minggu})$. Hasil analisis menunjukkan ada perbedaan asupan kalori $(\rho=0,000)$ dan tidak ada perbedaan asupan kalori pada minggu ke 2 , 3 , dan $4(\rho \geq 0,050)$.

Pengukuran berat badan dilakukan sebelum pemberian perlakuan (awal), setelah 7, 14, 21, dan 28 hari pemberian perlakuan. Data hasil pengukuran berat badan sebagaimana dapat dilihat pada Gambar2. 


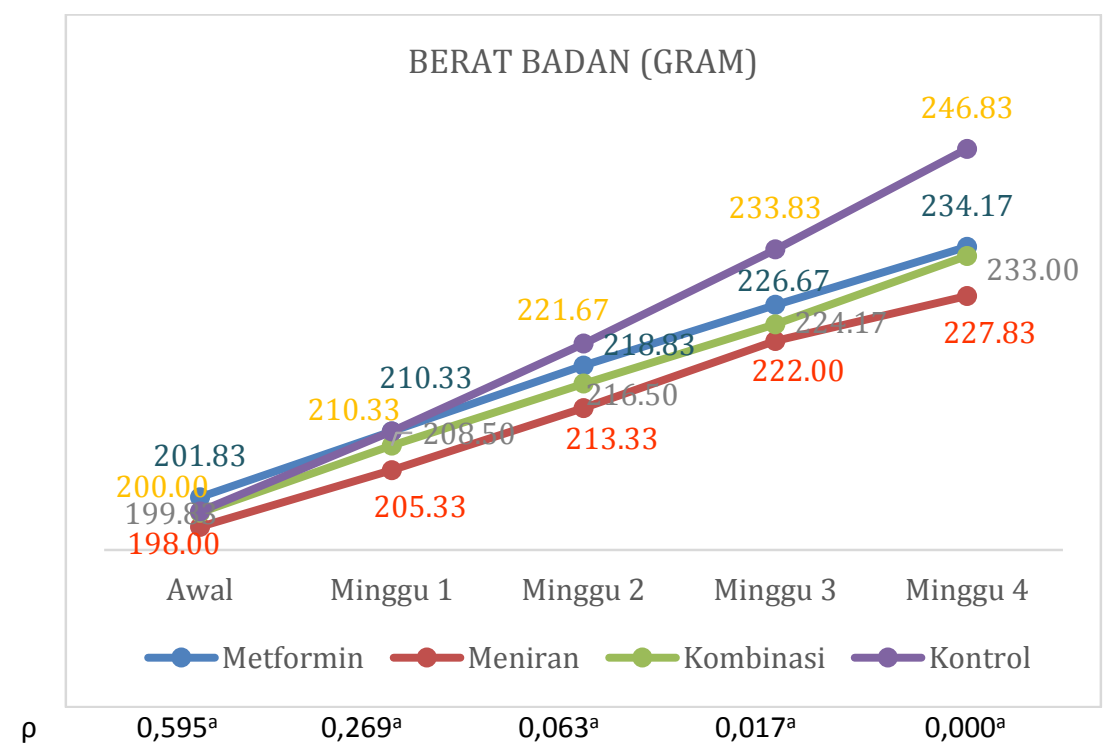

a Uji one way anova

Gambar 2. Grafik Berat Badan Hewan Coba (gram)

Gambar 2 menunjukkan bahwa semua kelompok hewan coba mengalami kenaikan berat badan sesuai dengan masa pertumbuhan hewan coba. Pada tiap periode pengukuran berat badan, kelompok hewan kontrol memiliki berat badan yang paling tinggi. Pada pengukuran awal, setelah perlakuan 1 dan 2 minggu tidak ada pebedaan berat badan antara kelompok $(\rho \geq 0,050)$ dan setelah pemberian perlakuan 3 dan 4 minggu ada perubahan. Untuk melihat pengaruh pemberian perlakuan maka dihitung perubahan berat badan setelah mendapat perlakuan 7, 14, 21, dan 28 hari sebagaimana disajikan pada Gambar 3.

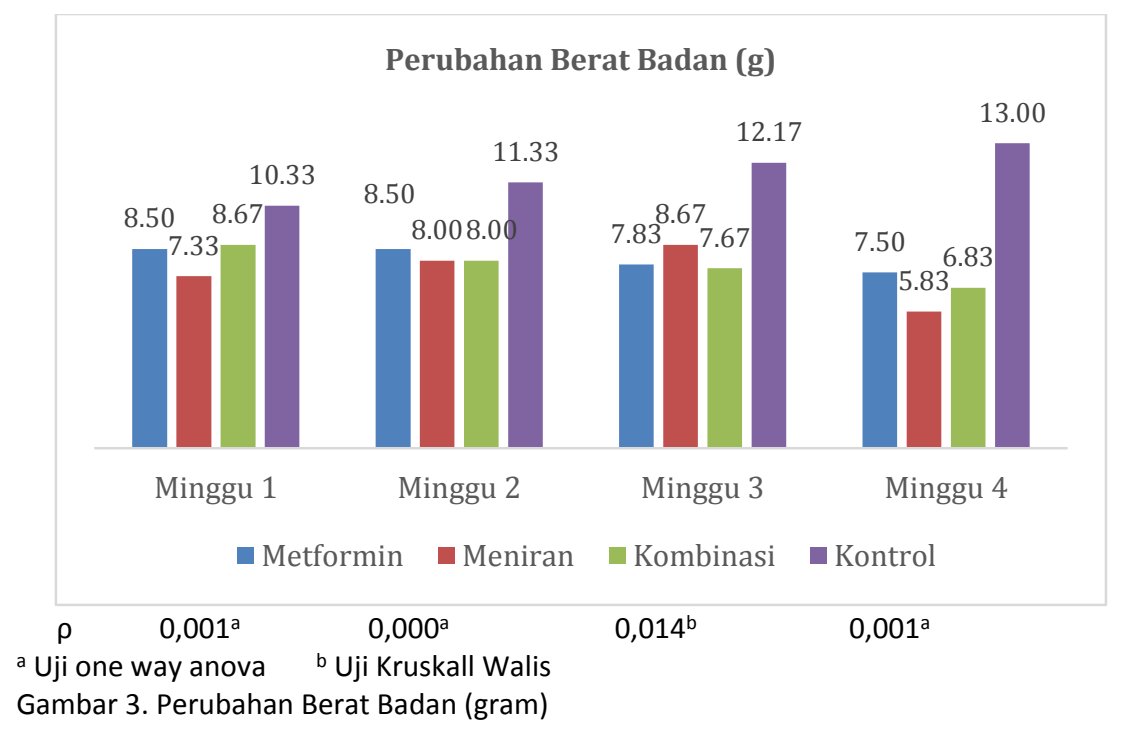

Grafik pada Gambar 3 menunjukkan bahwa kenaikan berat badan yang terbesar adalah pada kelompok kontrol. Ada perbedaan perubahan berat badan pada setiap periode pengukuran $(\rho<0,05)$. Dari hasil perhitungan indeks Lee diperoleh data status obesitas hewan coba seperti terlihat pada Gambar 4; 


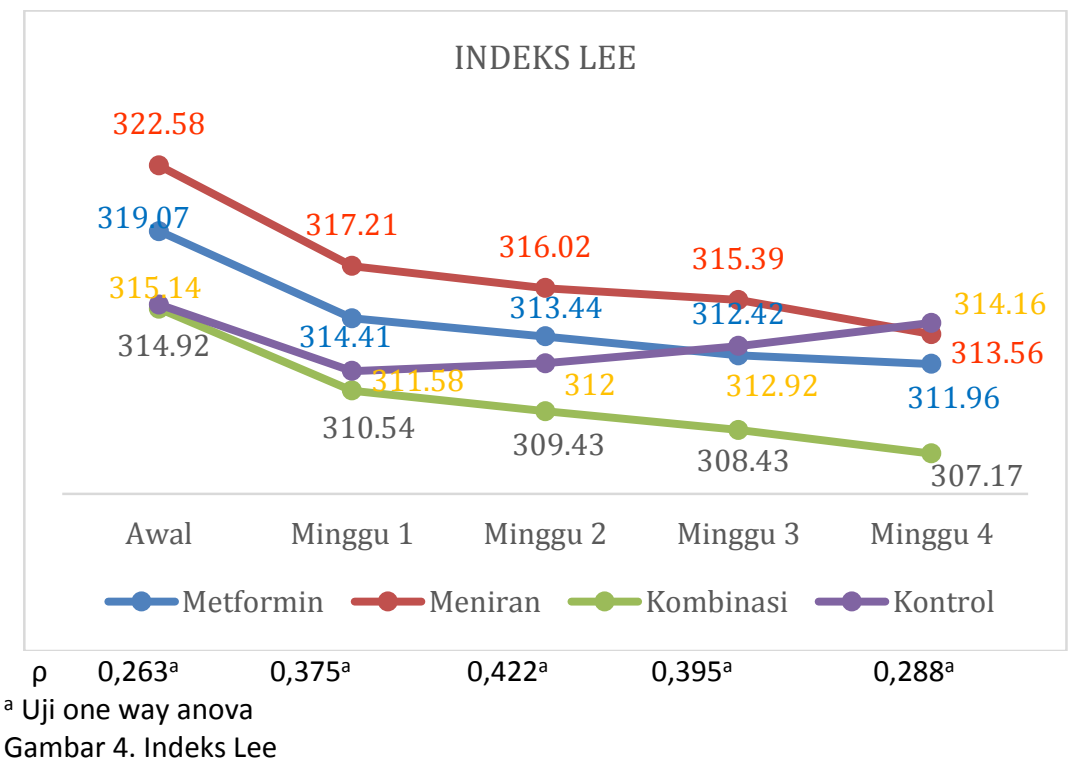

Grafik pada Gambar 4 menunjukkan bahwa semua kelompok yang mendapat perlakuan mengalami penurunan indeks Lee menunjukkan bahwa pemberian metformin, ekstrak air meniran, atau kombinasi metformin dan ekstrak air meniran memberikan efek memperbaiki status obesitas. Hewan coba kelompok control mengalami kenaikan indeks Lee. Pemberian perlakuan selama 28 hari belum dapat memperbaiki status obesitas secara total karena semua hewan coba masih memiliki indeks Lee $>300$. Tidak ada perbedaan indeks Lee antara kelompok perlakuan $(\rho>0,05)$. Perubahan indeks Lee untuk tiap kelompok hewan coba diperlihatkan pada Gambar 5.

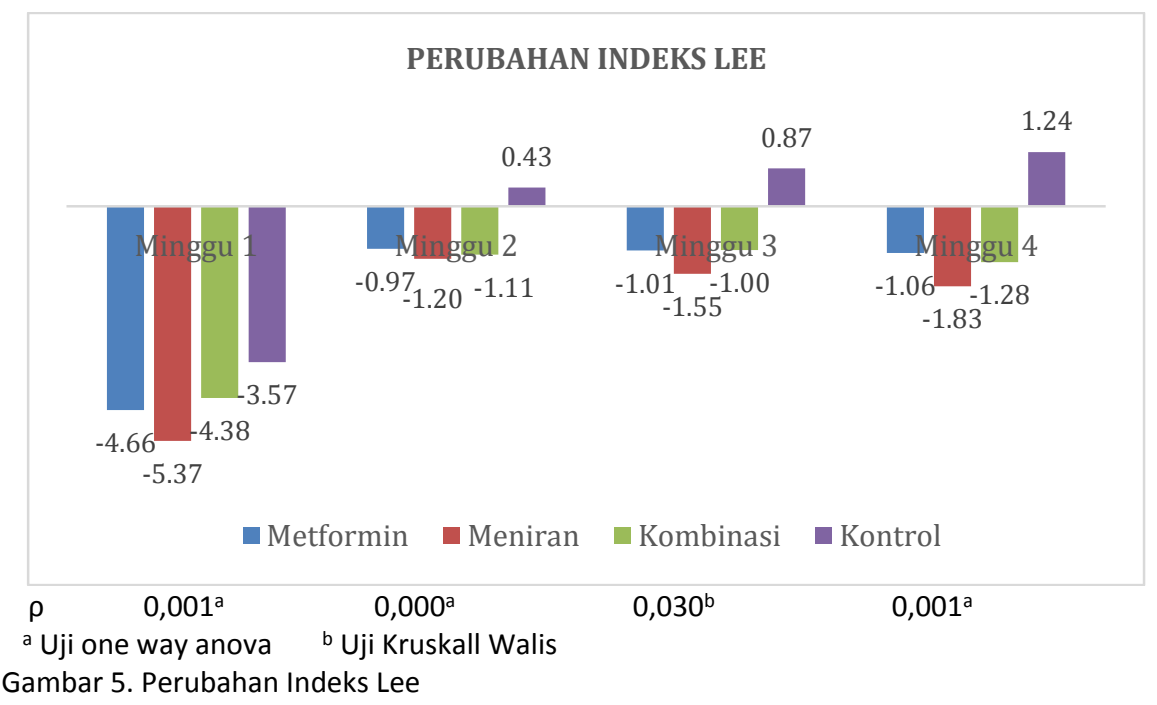

Data pada Gambar 5 menunjukkan ada perbedaan perubahan indeks Lee pada semua kelompok hewan coba. Kelompok yang diberi perlakuan metformin $45 \mathrm{mg} / \mathrm{kg} \mathrm{BB} /$ hari, ekstrak air meniran $400 \mathrm{mg} / \mathrm{kg} \mathrm{BB} /$ hari, dan kombinasi metformin $45 \mathrm{mg} / \mathrm{kg} \mathrm{BB} /$ hari, dengan ekstrak air meniran $400 \mathrm{mg} / \mathrm{kg}$ BB/hari mengalami penurunan indeks Lee sedangkan kelompok kontrol mengalami peningkatan indeks Lee. Kelompok hewan coba yang memiliki indeks Lee terendah adalah kelompok yang diberi kombinasi metformin $45 \mathrm{mg} / \mathrm{kg}$ BB/hari, dengan ekstrak air meniran $400 \mathrm{mg} / \mathrm{kg} \mathrm{BB} /$ hari.

Pemberian kombinasi metformin dengan dosis 45 $\mathrm{mg} / \mathrm{kg} \mathrm{bb} /$ hari dan ekstrak air meniran dengan dosis 400 $\mathrm{mg} / \mathrm{kg} \mathrm{bb} /$ hari sudah terlihat pengaruhnya terhadap pengendalian kenaikan berat badan dan penurunan

indeks Lee, mulai dari setelah perlakuan 7 hari sampai akhir perlakuan (28 hari). Pemberian kombinasi metformin dan ekstrak air meniran memberikan pengaruh yang berbeda dengan pemberian tunggal metformin atau ekstrak air meniran.

Pencegahan obesitas secara efektif yang harus dimulai dari awal dengan mendorong aktivitas fisik dan pola makan sehat. Obesitas merupakan suatu kondisi yang disebabkan karena ketidakseimbangan asupan dan keluaran energi, sehingga kelebihan energi terakumulasi dalam lemak tubuh. Prevalensi obesitas terus meningkat karena perubahan diet dan dan pola aktivitas sebagai hasil dari perubahan budaya ${ }^{5}$.

Obesitas menyebabkan resistensi insulin melalui hiperinsulinemia sebagai akibat dari insulinemia perifer, 
dari peningkatan asam lemak bebas dalam hati dan penghambatan pembersihan insulin hepatik yang bisa menyebabkan penurunan sensitivitas insulin perifer. ${ }^{18}$ Obesitas memiliki kecenderungan untuk menghasilkan banyak asam lemak bebas dalam hati dan mengarah ke hipertrigliseridemia dan peningkatan produksi VLDL. Kondisi hiperlipidemia juga dapat ditemukan pada obesitas sebagai tingginya LDL dan rendahnya HDL. Obesitas (BMI > $30 \mathrm{~kg} / \mathrm{m}^{2}$ ) juga membawa tiga kali peningkatan risiko kematian dini. ${ }^{18}$ Perbaikan status obesitas dapat dilakukan secara farmakologi yaitu dengan penggunaan obat oral metformin.

Metformin (dimethylbiguanide) adalah agen farmakologi oral yang berfungsi sebagai agen insulinsensitizing dan anti hiperglikemik yang selain digunakan dalam pengobatan diabetes tipe 2 dan risiko kardiovaskular, tetapi juga menghasilkan penurunan berat badan yang sederhana dan tahan lama. ${ }^{7,19}$ Efek penurunan berat badan oleh metformin terjadi melalui pengurangan aktivitas AMPK hipotalamus, yang menurunkan NPY (oreksigenik), dan meningkatkan ekspresi POMC (anorektik) pada saraf pusat sehingga mengurangi nafsu makan. ${ }^{19}$

Metformin menginduksi penurunan berat badan pada individu overweight dan obesitas yang berisiko diabetes mellitus tipe 2. Penggunaan metformin untuk menurunkan berat badan dapat terangkan melalui hubungannya dengan agen penekan nafsu makan seperti phentermine, topiramate, dan lorcaserin yang belum banyak dibahas secara klinis. ${ }^{19}$ Metformin terbukti merupakan obat yang efektif untuk menurunkan berat badan pada pasien obesitas non diabetik. ${ }^{20}$

Berbagai penelitian pada tikus diabetik yang diinduksi streptozotocin menunjukkan bahwa pemberian ekstrak meniran dapat menurunkan berat badan. ${ }^{12,13}$ Senyawa saponin dapat menghambat absorpsi karbohidrat melalui penghambatan enzim perncernaan, penghambatan transport aktif glukosa melalui brush border usus, dan penundaan laju pengosongan alat pencernaan. ${ }^{21}$ Selain itu kehadiran alkaloid bersama plavonoid dengan jumlah besar dalam ekstrak air meniran dalam saluran pencernaan mengurangi penyerapan glukosa makanan. ${ }^{22}$ Meniran sebagai astrigen berfungsi mempresipitasikan protein selaput lendir usus dan membentuk lapisan pelindung usus, menghambat asupan glukosa yang menyebabkan peningkatan glukosa darah tidak terlalu tinggi. Meningkatkan kecepatan pengeluaran glukosa dari sirkulasi, dengan cara mempercepat peredaran darah yang berkaitan dengan kerja jantung melalui percepatan filtrasi dan ekskresi ginjal, sehingga produksi urin meningkat, laju ekskresi glukosa lewat ginjal meningkat. Kandungan serat larut yang tinggi dalam tanaman meniran menunda penyerapan glukosa. ${ }^{23}$

Pemberian kombinasi metformin dengan dosis 45 $\mathrm{mg} / \mathrm{kg} \mathrm{BB} /$ hari dan ekstrak air meniran $400 \mathrm{mg} / \mathrm{kg} \mathrm{BB} /$ hari dapat mengendalikan kenaikan berat badan dan menurunkan indeks Lee secara bersamaan melalui penghambatan penyerapan karbohidrat, penundaan rasa lapar pada lambung, dan mempercepat ekskresi glukosa melalui ginjal

Penggunaan air sebagai pelarut yang digunakan untuk mengekstrak meniran menjadi kelebihan penelitian ini, karena dengan demikian bisa menjadi rujukan bila mana akan dilakukan penelitian lanjutan mengenai air seduhan meniran. Dibalik manfaat dan efektifitas meniran yang dikombinaskan dengan metformin, diperlukan uji efek negatif atau toksisitas meniran pada tubuh sebelum dimanfaatkan sebagai minuman basis herbal.

\section{KESIMPULAN}

Pemberian kombinasi metformin dengan dosis 45 $\mathrm{mg} / \mathrm{kg} \mathrm{BB} /$ hari dan ekstrak air meniran $400 \mathrm{mg} / \mathrm{kg} \mathrm{BB} /$ hari dapat memperbaiki status obesitas pada tikus Sprague dawley jantan obesitas. Diperlukan studi lanjut mengenai efek toksikologi daripemberan ekstark air meniran dan metformin melalui pengujian pada organ hati, ginjal, dan saluran cerna.

\section{ACKNOWLEDGEMENT}

Prof. Dr. JB Suparyatmo, Sp.PK(K) (UNS), Prof dr. Lisyani Suromo, Sp.PK(K) (Undip), Prof.Dr. dr. Hardhono Susanto, PAK(K) (undip) dan Dr. dr. Tjokorda Gde Dalem Pemayun, Sp.PD-KMED, terimakasih telah menjadi narasumber selama melaksanakan penelitian dan penulisan laporan penelitian.

\section{REFERENSI}

1. Westerink, J. \& Visseren, F. L. J. Pharmacological and non-pharmacological interventions to influence adipose tissue function. Cardiovasc. Diabetol. 10, 13 (2011).

2. WHO. Obesity and overweight. (2018).

3. Kemenkes Republik Indonesia. Potret sehat indonesia dari riskesdas 2018. (2018).

4. Kim, K.-B. \& Shin, Y.-A. Males with Obesity and Overweight. J. Obes. Metab. Syndr. 29, 18-25 (2020).

5. Taghavi, S. A., van Wely, M., Jahanfar, S. \& Bazarganipour, F. Pharmacological and nonpharmacological strategies for obese women with subfertility. Cochrane Database Syst. Rev. 2017, (2017).

6. Beatriz, L., Rojas, A. \& Gomes, M. B. Metformin : an old but still the best treatment for type 2 diabetes. Diabetol. Metab. Syndr. 5, 1 (2013).

7. Azcona-sanjulián, M. C., Lambán, A. C. \& Ruiz, B. L. Six-Month Therapy with Metformin in Association with Nutritional and Life Style Changes Obesity in Children and Adolescents with Obesity. Int. J. Pediatr. Res. 1, 1-6 (2015).

8. Wang, Y. W. et al. Metformin: A review of its potential indications. Drug Des. Devel. Ther. 11, 2421-2429 (2017).

9. Narendra, K., Swathi, J., Sowjanya, K. \& Satya Savithri, A. Phyllanthus niruri: a review on its ethno botanical, phytochemical and pharmacological profile. J. Pharm. Res. 5, 46814691 (2012).

10. Okoli, C., Ezike, A. \& Akah, P. Evaluation of antidiabetic potentials of Phyllanthus niruri in alloxan diabetic rats Evaluation of antiplasmodial natural products View project Natural Products 
View project. African J. Biotechnol. 9, 248-259 (2010).

11. S. Thiangthuma, B. Dejaeghera, M. Goodarzia, C. Tistaerta, A.Y. Gordienc, N. Nguyen Hoaid, M. Chau Vand, J. Quetin-Leclercqc, L. Suntornsukb, Y. V. H. Potentially antioxidant compounds indicated from Mallotus and Phyllanthus species fingerprints. J. Chromatogr. 114-121 (2012).

12. Adeneye, A. A., Amole, O. O. \& Adeneye, A. K. Hypoglycemic and hypocholesterolemic activities of the aqueous leaf and seed extract of Phyllanthus amarus in mice. Fitoterapia 77, 511514 (2006).

13. Shetti, A. A., Sanakal, R. D. \& Kaliwal, B. B. Antidiabetic effect of ethanolic leaf extract of Phyllanthus amarus in alloxan induced diabetic mice. 2, 11-15 (2012).

14. Kosnayani, A. S., Hidayat, A. K., Darmana, E., Riwanto, I. \& Hadisaputro, S. Effective combination of Phyllanthus niruri Linn. and metformin to improve insulin resistance in obese rats. Int. J. Innov. Creat. Chang. 9, 167-176 (2019).

15. Asare, G. A. et al. Acute toxicity studies of aqueous leaf extract of Phyllanthus niruri. Interdiscip. Toxicol. 4, 206-210 (2011).

16. Oyewo, Bukoye, E., Akanji, Adewumi, M. \& Adekunle, A. S. Immunomodulation Capabilities of Aqueous Leaf Extract of Phyllanthus amarus in male Wistar Rats. Rep. Opin. 4, 22-37 (2012).

17. Rogers, P. \& Webb, G. P. Estimation of body fat in normal and obese mice. Br. J. Nutr. 43, 83 (1980).

18. S., C., H, E., J, B. \& B, S. Obesity: Handbook of General Practice. (Oxford University Press, 2002).

19. Malin, S. K. \& Kashyap, S. R. Effects of metformin on weight loss : potential mechanisms. 323-329 (2014) doi:10.1097/MED.0000000000000095.

20. Seifarth, C., Schehler, B., Schneider, H. J., Clin, E. \& Diabetes, E. E ff ectiveness of Metformin on Weight Loss in Non-Diabetic Individuals with Obesity. 27-31 (2012).

21. Tiwari, A. K. \& Rao, J. M. Diabetes mellitus and multiple therapeutic approaches of phytochemicals: Present status and future prospects. (2002).

22. Khanna, A. K., Rizvi, F. \& Chander, R. Lipid lowering activity of Phyllanthus niruri in hyperlipemic rats. J. Ethnopharmacol. 82, 19-22 (2002).

23. Karuna, R., Reddy, S. S., Baskar, R. \& Saralakumari, D. Antioxidant potential of aqueous extract of Phyllanthus amarus in rats. Indian J. Pharmacol. 41, 64-7 (2009). 